\title{
Regional housing market in Russia: analysis of dependencies between indicators of migration, construction volume and housing affordability
}

\author{
Andrey Klypin \\ GBO «Mosstroyrazvitie», \\ Moscow, Russia \\ e-mail: research.klypin@gmail.com
}

\author{
Sergey Vyunov \\ GBO «Mosstroyrazvitie», \\ Moscow, Russia \\ e-mail: vyunov25@gmail.com
}

\begin{abstract}
The article deals with the correlation between the migration level, construction volume, salary level and the price per square meter of housing in the regions of Russia. To conduct the study the authors selected 46 Russian regions based on the level of GDP. Factors, affecting the net migration rate, as well as preferable destination points are determined. The housing affordability index, reflecting the comparability between the housing price and the average salary level, is calculated for each region. Housing affordability is identified as high for Ural and Far East Federal districts. Average values of the index are noted for the Southern, Volga and Central Federal districts, while cities of federal importance fall to the group of outsiders. Dependence of share of migrants in total region population on the amount of housing put in operation is stated. In the end of the paper measures of construction industry development and state regulation, aiming to reduce the regional problem of housing affordability, are proposed.
\end{abstract}

Keywords - housing affordability, housing market, migration outflow, regional economic development

\section{INTRODUCTION}

Being one of the fundamental industries, construction has a special place in exchange economy.

Housing market is probably the most significant segment of construction industry and has a special social burden. The level of investment and construction activity, as well as, housing accessibility, directly affect the quality of life. Massmarket housing forms the basis for the further overall socioeconomic development.

The primary barrier or determinant to economic development of the region through the implementation of employment capacity is the accommodation issue [1]. Job hunting difficulties can be overcome over time by formal or informal methods, for instance on acquaintance or through employment service, whereas housing is an entirely different matter due to the greater labor market flexibility in relation to the housing market.

\section{MATERIALS AND Methods (MODEL)}

To conduct the analysis 46 regions of Russia were selected according to their GRP rating in 2011-2016. Federal districts capitals, 10 regions-leaders, average and outsiders (10 each) by their index of GRP in 2015 are included in the studied list. Russian Federal state statistics service database was used to receive the analysis base [2].

Through exploring the theme of urban development and regional housing market dynamics, dependence between the indicators of the volume of construction and migration outflow, the earning per person and housing price per sqm in different territories of Russia_are identified.

\section{RESULTS AND DISCUSSION}

In Russia housing is not the first year subject of commerce, meanwhile regional housing market of the country shows different levels of advancement. Some authors take into consideration not only quantitative indicators - sqm put into operation, compliance of the level of wages to prices per sqm, but qualitative as well: the level of mortgage development, housing safety, comfort, ecological properties [3].

\section{A. Housing and adjacent areas development indicator}

One of the most famous rating of the urban environment quality index for different Russian cities, estimating the development of housing and adjacent areas, demonstrated the serious value diversity.

For instance, despite the population of more than a million people, Volgograd has one of the lowest ranks (Fig 1). Its safety parameter, reflecting the rate of dilapidated housing received the least number of points possible. Volgograd region program dealing with resettlement from dilapidated housing faced certain difficulties at the stages of its implementation. In 2014 it was almost canceled threatening Volgograd region with the suspension of federal funding. Serious efforts were required to ensure its further implementation. At the same time, changes in the regional program of preferential mortgage lending ${ }^{1}$ allowed to achieve $37.6 \%$ growth in the value of loans disbursed, which is by $3.3 \%$ higher than the average Russian indicator.

\footnotetext{
1 The order of the Ministry of construction of the Volgograd region of 15.08 .2014 g. № 732-OD «On issues of the program «Housing for the Russian family» in the framework of the state program of the Russian Federation «Affordable and comfortable housing and communal services submission for of citizens of the Russian Federation» in the Volgograd region»
} 


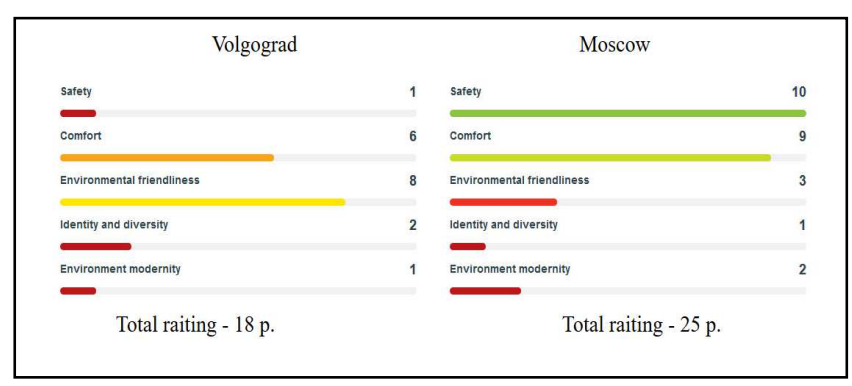

Fig. 1 Housing and adjacent areas development index comparison for Volgograd and Moscow.

Moscow, on the other hand, is recognized to have the most comfortable urban environment. The city gained 25 points of housing and adjacent areas development index and became the only one with condition estimated as good.

\section{B. Price per square meter and migration metrics}

The price per square meter of housing is determined by the influence of many factors: international and countrywide (oil prices and oil market conjuncture, currency quotation [4], central bank rate, access to international capital markets, investment activity), regional (geographic condition and valid policy), local (sectoral structure of the economy, local resource prices) $[5,6]$.

We have conducted analysis of the studies on the subject $[7,8]$ to identify 3 main factors that directly affect the parameter: nominal salary amount, amount of sqm put in operation, amount of human migration.

All regions were divided into 3 groups by the value of the indicator: «leaders», characterized by the highest housing prices (more than $25 \%$ of the average Russian value), «the average regions» and «the outsiders» (below $25 \%$ of average). Full cast of leaders and outsiders of the indicator is listed in Fig.

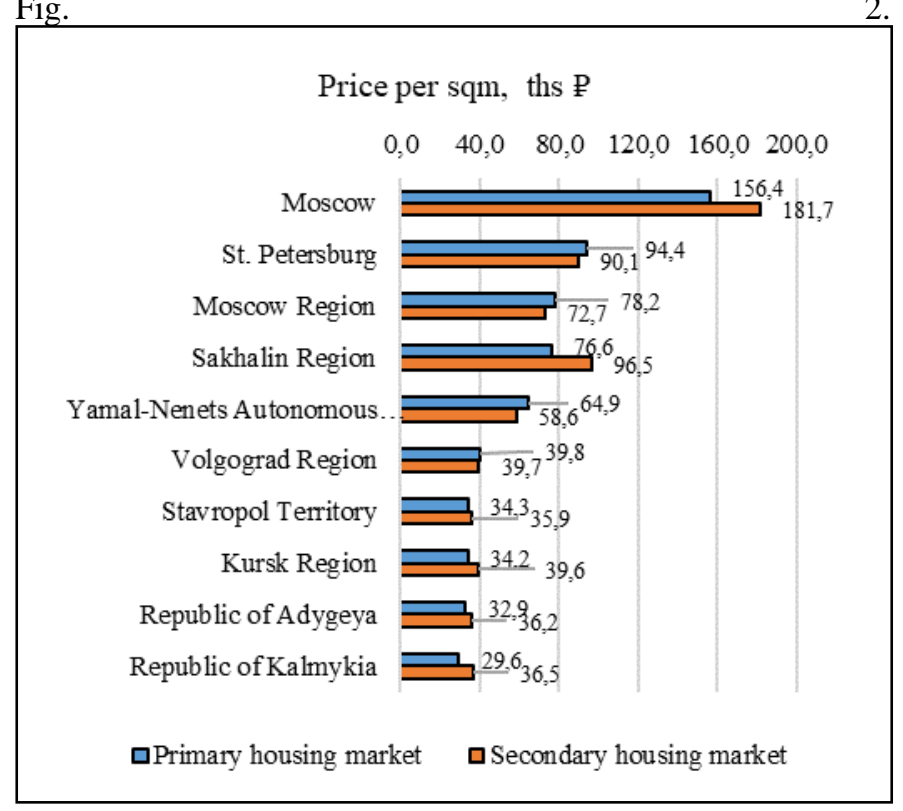

Fig. 2 Regional leaders/outsiders in housing market in 2016
The transition from one group to another during the review period was stated only for $7 \%$ of the studied regions.

The absolute leader in price per square meter, Moscow, occupies a special position in the hierarchy, being two times ahead of other regions. The group of leaders consists of St. Petersburg, Moscow region, Yamal-Nenets Autonomous Area and Sakhalin region as well.

The next step of the study is to identify migration metrics. Calculating the share of migrants in the total population of regions with different levels of GRP we get the following results (Fig. 3).

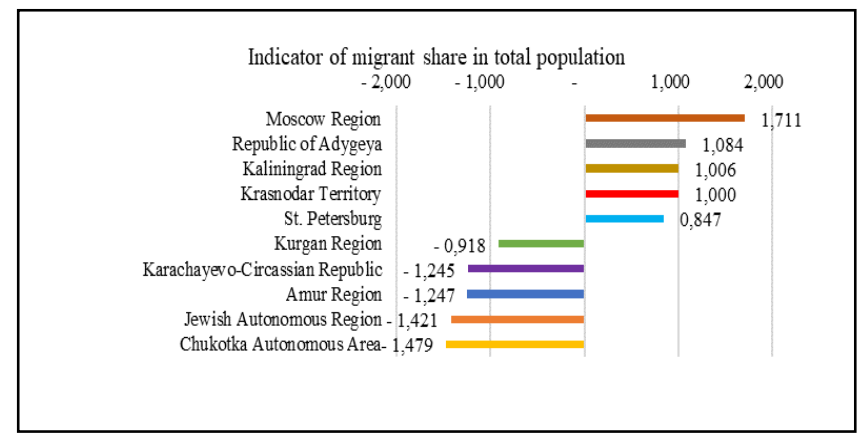

Fig. 3 Migrant share in total population in 2016

The majority of migrants tend to prefer more developed regions compared to the current residence [9], moving from sparsely populated areas with low wages to the nearby regional economic centers, where the prosperous employment is offered.

The possibility of moving into these regions from any other is restricted by «price distance». Housing affordability is an important criteria taken into consideration while choosing from the alternatives, since the labor relocation in Russia now is likely an irrevocable process and is associated with significant time and financial costs.

\section{Housing affordability index}

We analyzed house prices and earnings across Russia for the period between 2011 and 2016 and found that while the average price of a sqm had increased more than $21,1 \%$, from 40643 P to 49250 P, average salary had gone up by much more - by $55.2 \%$.

To identify comparability between the price of housing and average monthly nominal salaries in the regions, we calculated a housing affordability index that determines the sqm of housing that can be paid for with one month salary. Basic model of index calculation is chosen in the article [10].

The average country value of the index in 2016 is 0.67 sqm, which is 0.15 more than in 2011 for the primary housing market and 0.65 for the secondary housing market $(+0.12$ to the value of 2011). 


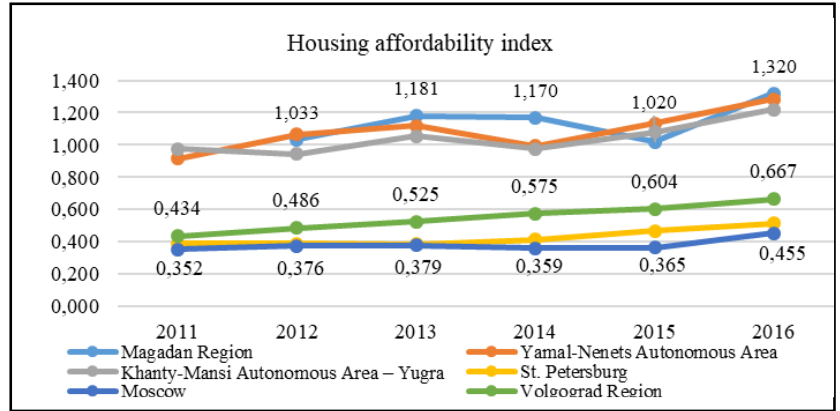

Fig. 4 Regional housing affordability index dynamics.

According to the calculations, citizens can purchase more than one square meter of living space per one salary only in 3 regions of Russia Fig.4

The highest level of housing affordability in Russia is noted in Ural and Far East Federal districts: the Magadan region, Yamalo-Nenets Autonomous Area, Khanty-Mansi Autonomous Area - Yugra and Sakhalin region. Residents of these regions can afford up to $1.32,1.28,1.21$ and $0.85 \mathrm{sqm}$ in the primary housing market and 1.36, 1.42, 1,30 and 0.67 sqm in the secondary one in 2016

However, the results of our study on another indicator testify these regions experience an outflow of population and the decline in housing construction in the considered period. The witnessed values are determined by low housing demand, resulting in low prices per sqm, and high salary level paid for working in harsh conditions.

Average values of the index correspond to the Southern, Volga and Central Federal districts. These regions are characterized with the migration outflow and the below the average values of housing construction and GRP indicators. The average index value states at 0.63 .

The situation with the regions at the bottom of the rating is ambiguous. The group includes Moscow (the lowest rank) and St. Petersburg, that are described by a high level of housing prices, backed by high values of GRP and demand for housing, as well as weak economically developed regions such as the Chechen Republic and Chukotka Autonomous Area, demonstrating huge gaps between average salaries and house prices.

\section{Value of housing put in operation}

The availability of housing increased by more than $50 \%$ in the primary market in the Kaluga, Ryazan and the Volgograd region, in the secondary - in St. Petersburg, Ryazan and Kaluga region. Affordability of Moscow housing improved by $27 \%$ and $42.3 \%$, respectively.

The composition of the group of leaders and outsiders, formed by the parameter, remained stable during the reviewed period. Moscow and the Moscow region, actively implementing a housing renovation program, as well as St. Petersburg, Krasnodar region and Republic of Bashkortostan belonged to the group of leaders at all points of analyzed period. Fig. 5.

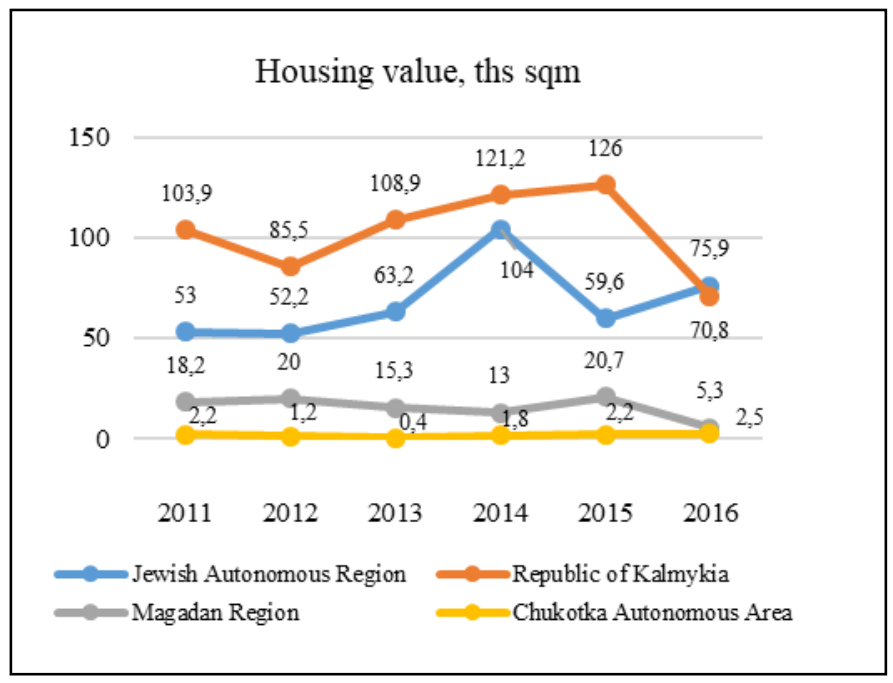

Fig. 5 Leaders in the value of housing put in operation, 2016.

The regions of Far Eastern Federal district form the group of outsiders. A small amount of housing there is accompanied by migration outflow. Fig. 6

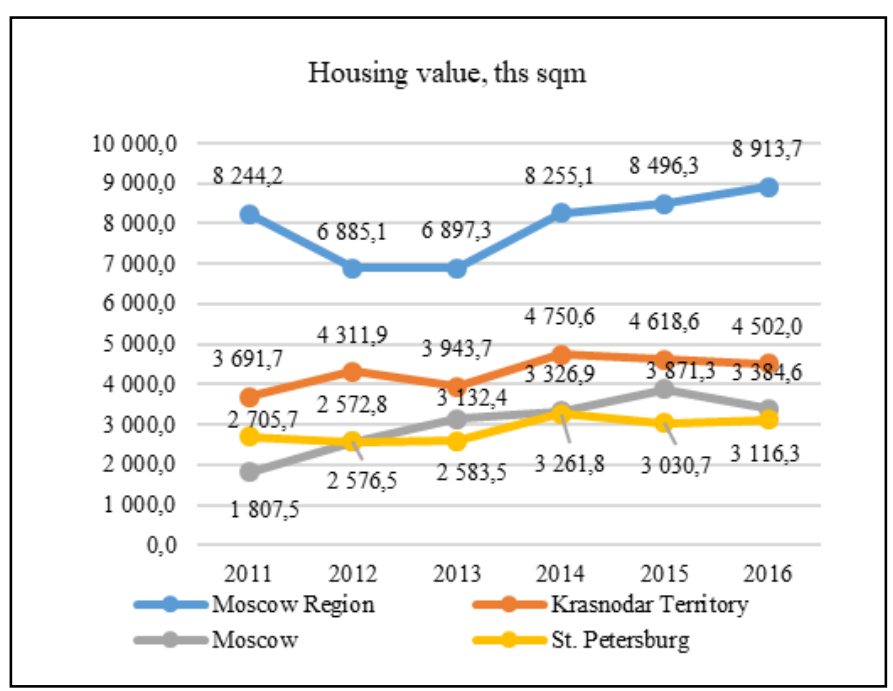

Fig. 6 Outsiders in the value of housing put in operation, 2016.

\section{E. Recommendations for government of Russia on regulation of the construction industry}

The following measures of construction industry development can be proposed to alleviate the housing affordability problem.

- Development of interaction mechanisms among potential stakeholders, taking into account difference in their goals and interest in construction projects and programs;

- Achieving balance in local manufacturing and interregional shipment of construction materials; 
- Insurance of state order for construction activities and materials;

- State tax and financial support for the construction enterprises under condition of implementation of strict and independent control over the targeted use of allocated funds;

- Compulsory certification of the main and innovative materials affecting the safety and sustainability in design and construction;

- Development of public-private partnership mechanisms as a source of accumulation of additional funds.

Assuming stability of other sectors, implementation of moderate state control in construction industry and development of cooperation between the government, private sector and scientific and expert community will help to reduce tension with housing affordability issue.

\section{CONCLUSION}

The connection between the housing affordability, housing and adjacent area level, inter-regional migration and construction volume in the regions is complex and geographically specific (Table 1, Fig. 7).

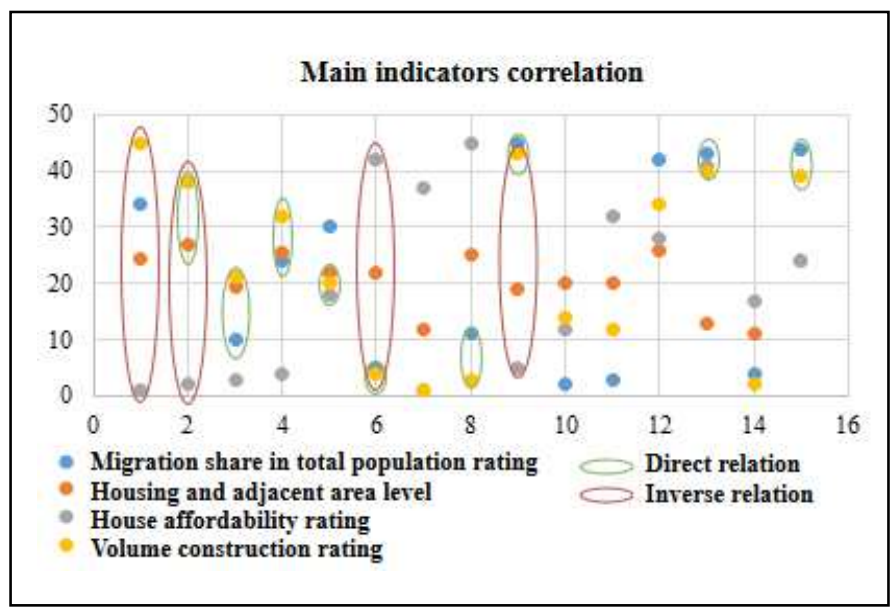

Fig. 7 Correlation of housing affordability, housing and adjacent area level, inter-regional migration and construction volume
TABLE 1 Regional rating in 2016

\begin{tabular}{|c|c|c|c|c|c|c|}
\hline № & Region & 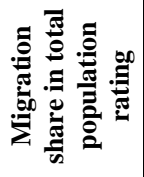 & 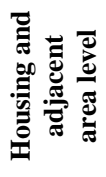 & 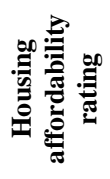 & مْ & 此 \\
\hline 1 & Magadan Region & 34 & 24 & 1 & 45 & 38 \\
\hline 2 & $\begin{array}{c}\text { Yamal-Nenets } \\
\text { Autonomous } \\
\text { Area } \\
\end{array}$ & 38 & 27 & 2 & 38 & 7 \\
\hline 3 & $\begin{array}{c}\text { Khanty-Mansi } \\
\text { Autonomous } \\
\text { Area - Yugra }\end{array}$ & 10 & 19 & 3 & 21 & 3 \\
\hline 4 & Sakhalin Region & 24 & 25 & 4 & 32 & 14 \\
\hline 5 & $\begin{array}{l}\text { Volgograd } \\
\text { Region }\end{array}$ & 30 & 22 & 18 & 20 & 16 \\
\hline 6 & St. Petersburg & 5 & 22 & 42 & 4 & 4 \\
\hline 7 & Moscow region & 1 & 12 & 37 & 1 & 2 \\
\hline 8 & Moscow & 11 & 25 & 45 & 3 & 1 \\
\hline 9 & $\begin{array}{c}\text { Jewish } \\
\text { Autonomous } \\
\text { Region }\end{array}$ & 45 & 19 & 5 & 43 & 45 \\
\hline 10 & $\begin{array}{c}\text { Republic of } \\
\text { Adygeya }\end{array}$ & 2 & 20 & 12 & 14 & 37 \\
\hline 11 & $\begin{array}{c}\text { Kaliningrad } \\
\text { Region }\end{array}$ & 3 & 20 & 32 & 12 & 26 \\
\hline 12 & Kurgan Region & 42 & 26 & 28 & 34 & 32 \\
\hline 13 & $\begin{array}{c}\text { Karachayevo- } \\
\text { Circassian } \\
\text { Republic } \\
\end{array}$ & 43 & 13 & 41 & 40 & 40 \\
\hline 14 & $\begin{array}{l}\text { Krasnodar } \\
\text { Territory }\end{array}$ & 4 & 11 & 17 & 2 & 5 \\
\hline 15 & Amur Region & 44 & 24 & 24 & 39 & 30 \\
\hline
\end{tabular}

\section{A. Volume of construction and migration level correlation}

Price is primarily determined by the demand and supply migration movements within the country and level of housing offer.

The correlation between the volume of construction and the share of migrants in the total population is noticed for all the studied regions. For regions with high level of housing put in operation (Moscow, Moscow region, St Petersburg, Krasnodar Territory) high population growth is registered and vice versa: relatively small housing volumes correspond with migration outflow (Magadan Region, Jewish Autonomous Region, Karachayevo-Circassian Republic, Amur Region).

\section{B. Volume of housing and housing affordability correlation}

Disproportionate economic development of regions determines gaps between «rich» regions (capitals; regions led by agglomerations; regions with natural resource) and «indigent» ones, therefore, contributing to housing price variety.

In this regard, a large number of regions of the list show the inverse relation between the indicator of housing affordability and the volume of housing input. That is why high volume of residential real estate in operation tends to mean its low accessibility (Moscow, Moscow Region, SaintPetersburg, Kaliningrad Region) and vice versa (Magadan Region, Jewish Autonomous Region, Amur Region, YamalNenets Autonomous Area). 
C. Level of housing and adjacent spaces and the volume of construction correlation

The indicator of the level of housing and adjacent area reflects the level of safety, comfort, environmental friendliness, modernity, identity and diversity of the urban environment. Most regions are characterized by a direct dependence of this indicator on the volume of new housing. Leading regions in terms of housing input (Moscow, Moscow region and St. Petersburg) demonstrate high values of indicator, that correspond to the progressive qualitative renewal of housing stock, the development of design technologies and urban planning. Low values on the contrary explicate a high proportion of standard economy class housing.

\section{References}

[1] Mkrtchyan N.V., Russia on the edge of demographic challenges. Report on human development in the Russian Federation, 2008 [Rossiya pered litsom demograficheskikh vyzovov. Doklad o razvitii chelovecheskogo potentsiala v Rossiiskoi Federatsii 2008 ] -M.:, 2009, 80-96 pp.

[2] Russian Federal state statistics service. URL: http://www.gks.ru

[3] Urban environment quality index, prepared by Ministry of Construction, Housing and Utilities of the Russian Federation, The Agency for
Housing Mortgage Lending, Strelka KB URL: http://индексгородов.рф

[4] N. Kornilov., «The influence of oil prices on residential real estate prices», Russian journal of entrepreneurship. [ «Vliyanie tsen na neft' na stoimost' zhiloi nedvizhimosti», Rossiiskoe predprinimatel'stvo.] - 2015. - vol. 16. - №. 10. -1483-1494 pp.

[5] Sevostyanov A.V. Real estate economics [Ekonomika nedvizhimosti] St. Pb. Lan, 2000. - 276 p.

[6] E. Sedova, O. Stebunova, S. Ushatova, «Econometric modeling of residential property prices at regional level: hierarchical approach», Intelligence. Innovations. Investment. [«Ekonometricheskoe modelirovanie stoimosti zhiloi nedvizhimosti na regional'nom urovne: ierarkhicheskii podkhod», Intellekt. Innovatsii. Investitsii.] - 2016. - №. 4. $-51-56 \mathrm{pp}$.

[7] Taylor. J. E.; International migration and economic development, 2006, $28 \mathrm{p}$.

[8] Swann R.. \& Co, Population Growth and Housing Expansion in the UK, 2013, 83 p.

[9] Monnet E., Wolf C., Demographic cycles, migration and housing investment, Journal of Housing Economics, 2017, vol. 38, 38-49 pp.

[10] Rudi L.Yu., Tropnikova T.A., «Methodological approaches to the definition of housing affordability and their application» [«Metodicheskie podkhody $\mathrm{k}$ opredeleniyu pokazatelya dostupnosti zhil'ya i ikh primenenie»], № 34, 27-33 pp. 